\title{
Simple Sequence Repeat and S-Locus Genotyping to Assist the Genetic Characterization and Breeding of Polyploid Prunus Species, P. spinosa and P. domestica subsp. insititia
}

\author{
Júlia Halász, et al. [full author details at the end of the article]
}

Received: 31 October 2019 / Accepted: 28 May 2021 / Published online: 16 June 2021

(c) The Author(s) 2021

\begin{abstract}
Polyploid Prunus spinosa $(2 n=4 \times)$ and P. domestica subsp. insititia $(2 n=6 \times)$ represent enormous genetic potential in Central Europe, which can be exploited in breeding programs. In Hungary, 16 cultivar candidates and a recognized cultivar 'Zempléni' were selected from wild-growing populations including ten $P$. spinosa, four $P$. domestica subsp. insititia and three $P$. spinosa $\times P$. domestica hybrids $(2 n=5 \times)$ were also created. Genotyping in eleven simple sequence repeat (SSR) loci and the multiallelic $S$-locus was used to characterize genetic variability and achieve a reliable identification of tested accessions. Nine SSR loci proved to be polymorphic and eight of those were highly informative (PIC values > 0.7 ). A total of 129 SSR alleles were identified, which means 14.3 average allele number per locus and all accessions but two clones could be discriminated based on unique SSR fingerprints. A total of $23 S$-RNase alleles were identified and the complete and partial $S$-genotype was determined for 10 and 7 accessions, respectively. The DNA sequence was determined for a total of 17 fragments representing 11 S-RNase alleles. 'Zempléni' was confirmed to be self-compatible carrying at least one nonfunctional $S$-RNase allele $\left(S_{\mathrm{J}}\right)$. Our results indicate that the $S$-allele pools of wildgrowing $P$. spinosa and $P$. domestica subsp. insititia are overlapping in Hungary. Phylogenetic and principal component analyses confirmed the high level of diversity and genetic differentiation present within the analysed accessions and indicated putative ancestor-descendant relationships. Our data confirm that $S$-locus genotyping is suitable for diversity studies in polyploid Prunus species but non-related accessions sharing common $S$-alleles may distort phylogenetic inferences.
\end{abstract}

Keywords Prunus spinosa $\cdot$ Prunus domestica subsp. insititia $\cdot$ SSR $\cdot$ Selfincompatibility $\cdot S$-genotype $\cdot$ Polyploid

This article is a revised version of this article [1] published in Biochemical Genetics that has been retracted.

[1] Júlia Halász; Noémi Makovicz-Zsohár, Ferenc Szöke et al. Biochem Genet (2017). https://doi. org/10.1007/s10528-016-9768-3. 


\section{Introduction}

Prunus spinosa L. (blackthorn or sloe) is a plum species belonging to the Rosaceae family (Potter et al. 2007). The diversification of the Eurasian plums dates back to the Oligocene. It is most likely that the extant European lineages of $P$. spinosa, $P$. cerasifera Ehrh. (cherry plum, myrobalan) and P. domestica (European plum) descended from an ancestor that migrated from eastern Asia (Chin et al. 2014). P. spinosa has a tetraploid genome $(2 n=4 \times=32$; Reynders-Aloisi and Grellet 1994). Several diploid species were suspected to contribute to blackthorn genome including $P$. cerasifera and $P$. microcarpa C.A.Mey. (Eryomine 1990; Reynders-Aloisi and Grellet 1994) but a recent phylogenetic analysis suggests that $P$. spinosa has been formed from a diploid ancestor of $P$. ramburii as a result of a polyploidisation event (Reales et al. 2010). It was hypothesized that blackthorn had a key role in the formation of $P$. domestica genome due to an introgressive cross between cherry plum and blackthorn (Crane and Lawrence 1952; Zhebentyayeva et al. 2019); however, it has not yet been confirmed (Horvath et al. 2011).

P. domestica subsp. insititia $\mathrm{L}$. has been long regarded as a hexaploid $(2 n=6 \times=48)$ sub-species of $P$. domestica species (Bailey, 1925) and a phylogenetic analysis based on chloroplast DNA sequences supported this notion (Reales et al. 2010). It is a dwarfer and more compact tree with smaller leaves and fruit than other garden plums (Faust and Surányi 1999). Fruits are consumed fresh or processed and the plant is sometimes used as rootstock for garden plum cultivars. Blackthorn is a deciduous wild shrub or small tree, which is self-incompatible and insect-pollinated (Nunes et al. 2006). It propagates vegetatively through root suckers, while its seed is dispersed by mammals and birds (Guitian et al. 1993). Its fruit looks like a small plum, and is often picked in Europe from wild-growing shrubs. It is used to make the alcoholic beverage known as sloe gin but it is also suitable for canning and wine making (Ruiz-Rodríguez et al. 2014). Fruits of $P$. spinosa have great nutritional and functional potential, providing chemical compounds with presumably favourable health-effects (Erturk et al. 2012). The leaves and flowers can be used as tea or source of cosmetic compositions (Sipos and Szabó 2004).

Several companies were established to process different parts of this plant species and their raw material was collected from wild-growing plants. However, it might present problems. The places for collection are usually next to polluted highways and the wild-growing shrubs are not under plant protection, so they are very often infected by fungi (Kovács 2015). Collected fruits differ in quality and hence nowadays there is an increasing demand for the introduction of recognized cultivars with stable and desirable quality properties. Cultivation of commercial cultivars may help overcome such issues and wild genotypes are valuable resources for breeders. Primarily, some interspecific hybrids were bred as rootstocks for plums. Two blackthorn cultivars ('Nittel' and 'Merzig') were recognized in Germany (Zimmer 2011). However, market demand is varied and national variability can be exploited to satisfy it and hence a blackthorn breeding 
program has been initiated in Hungary. Main purposes of the project include increased yield, precociousness and bigger fruit size. However, nothing is known about the genetic background of the selected cultivar candidates. Natural hybridization occurs readily between different plum species and in most cases morphological delimitation of the hybrids is impossible (Nielsen and Olrik 2001). Natural hybridization of $P$. spinosa and hexaploid species occurs frequently. The hybrid plants are morphologically similar to $P$. spinosa but are pentaploids $(2 n=5 \times=40)$ (Halliday and Beadle 1983).

Until now, only few results were reported about the molecular analysis of the less-investigated $P$. spinosa. These papers mainly focused on genetic variability of natural wild populations. The first report highlighted many polymorphisms in the cpDNA of the wild shrub collected from seven deciduous forests across Europe (Mohanty et al. 2000). Later, 16 individual plants from wild populations of Turkey were sampled and subjected to RAPD analysis that proved to be a reliable method to examine genetic relatedness among blackthorn genotypes (Erturk et al. 2009). RAPD has been also efficiently used to evaluate the genetic differentiation of autochthonous blackthorn populations in Germany (Eimert et al. 2016). AFLP analysis was used to estimate the genetic variability of Belgian blackthorn populations and to assess their potential as seed source for gene conservation (Vander Mijnsbrugge et al. 2013) as well as to characterize the genetic differentiation among German, Italian and Hungarian populations influenced by vegetative regeneration and founder effect (Leinemann et al. 2014).

Simple sequence repeats (SSR) or microsatellites have been developed in many Prunus species, such as apricot, Japanese plum and cherry (Dirlewanger et al. 2002; Messina et al. 2004; Mnejja et al. 2004) and these markers proved to have high resolution ability to differentiate accessions. In addition, SSR markers developed in one species can be efficiently used in closely related species (Cipriani et al. 1999; Halász et al. 2019; Mnejja et al. 2004; Wünsch 2009). SSRs were also promising to distinguish polyploid $P$. cerasus (Lacis et al. 2011), P. domestica and $P$. d. subsp. insititia cultivars (Abdallah et al. 2019; Decroocq et al. 2004; Makovics-Zsohár et al. 2017; Urrestarazu et al. 2018) as well as P. spinosa (Horvath et al. 2011) genotypes.

Prunus species are mainly self-incompatible due to the genetically controlled rejection of self-pollens (De Nettancourt, 2001). This mechanism is commanded by the multiallelic $S$-locus that contains the pistil-expressed self-incompatibility ribonuclease ( $S$-RNase) and the pollen-expressed S-haplotype-specific F-box (SFB) genes (Hegedûs et al. 2012; Yamane and Tao 2009). S-genotyping of Prunus accessions is facilitated by the allele-specific intron length polymorphism (ILP) shown by both $S$-RNase introns (Wiersma et al. 2001; Sonneveld et al. 2003; Sutherland et al. 2004). Three $S$-RNase and $S F B$ alleles were sequenced in P. cerasifera $\left(S_{3}, S_{9}\right.$ and $\left.S_{10}\right)$ and $P$. domestica $\left(S_{5}, S_{6}\right.$ and $\left.S_{9}\right)$ by Sutherland et al. (2008). Recently, additional $S$-alleles have been identified and hexaploid plum cultivars have been $S$-genotyped (Makovics-Zsohár et al. 2016; Abdallah et al. 2019). The analysis of $S$-locus in $P$. spinosa focused primarily on the pollen-specificities and 37 SFB alleles were sequenced together with 7 S-RNase alleles (Nunes et al. 2006; Vieira et al. 2008).

The polyploid plum species grow wild and readily form interspecific hybrids in Hungary, a secondary centre of diversification, and such populations may provide 
genotypes selected for specific breeding purposes. The aim of this study was to estimate the genetic polymorphism of perspective blackthorn and plum genotypes selected in a Hungarian breeding program, to determine and characterize their $S$-RNase alleles and assess the overlap of $S$-allele pools among different plum species. We also wanted to evaluate the efficiency of SSR and $S$-locus markers in the genetic analysis of polyploid plum species.

\section{Materials and Methods}

\section{Plant Material}

A total of 16 polyploid plum (nine Prunus spinosa L., four P. domestica subsp. insititia L. and three $P$. spinos $a \times P$. domestica) cultivar candidates and a newly released blackthorn cultivar ('Zempléni') originated from different geographic locations (Supplementary Fig. 1) in the Carpathian basin (Hungary and Slovakia, Central Europe) were analysed in this study (Table 1). Scion wood was collected from the wild-growing perspective plants and grafted onto Myrobalan rootstocks. The trees were grown in an experimental orchard at Lövőpetri, Hungary, with $5 \mathrm{~m} \times 3 \mathrm{~m}$ spacing. All sampled plants were approx. 7 years old.

\section{Pollination Test}

Self-compatibility of 'Zempléni' cultivar was tested in the field in three subsequent years, 2016-2018, according to Nunes et al. (2006). Before anthesis, approximately 100 flower buds were bagged to exclude bees. Fruit development was continuously monitored, and the percentage of fruit set was recorded after two months.

\section{DNA Extraction and PCR Conditions}

Genomic DNA was extracted from fully expanded young leaves using a DNeasy Plant Mini Kit (Qiagen, Hilden, Germany). DNA concentrations and purification parameters were measured using a Nanodrop ND-1000 Spectrophotometer (Thermo Fisher Scientific, Waltham, MA, USA). For microsatellite analysis, a set of 11 SSR primer pairs were selected on the basis of previous reports on different Prunus species: CPSCT018, CPSCT 021 (Mnejja et al. 2004), CPDCT044 (Mnejja et al. 2005), ВРPCT007, ВРPCT025, ВРPCT037, ВРPCT038, ВРPCT039 and ВPPCT040 (Dirlewanger et al. 2002), EPDCU 5100 (Howad et al. 2005) and ASSR63 (Xie et al. 2006). The forward primers were labelled with 6-FAM fluorescent dye for detection in a capillary genetic analyzer. For $S$-genotype analysis, PCRs were performed using the consensus primer pairs of PaConsI-F/PaConsIR2 (the forward primer was fluorescently labelled with 6-FAM) amplifying the first intron of Prunus $S$-RNase gene, and PaConsII-F/PaConsII-R to amplify the second intron, according to the protocol described for the primers (Sonneveld et al. 2003, 2006). 


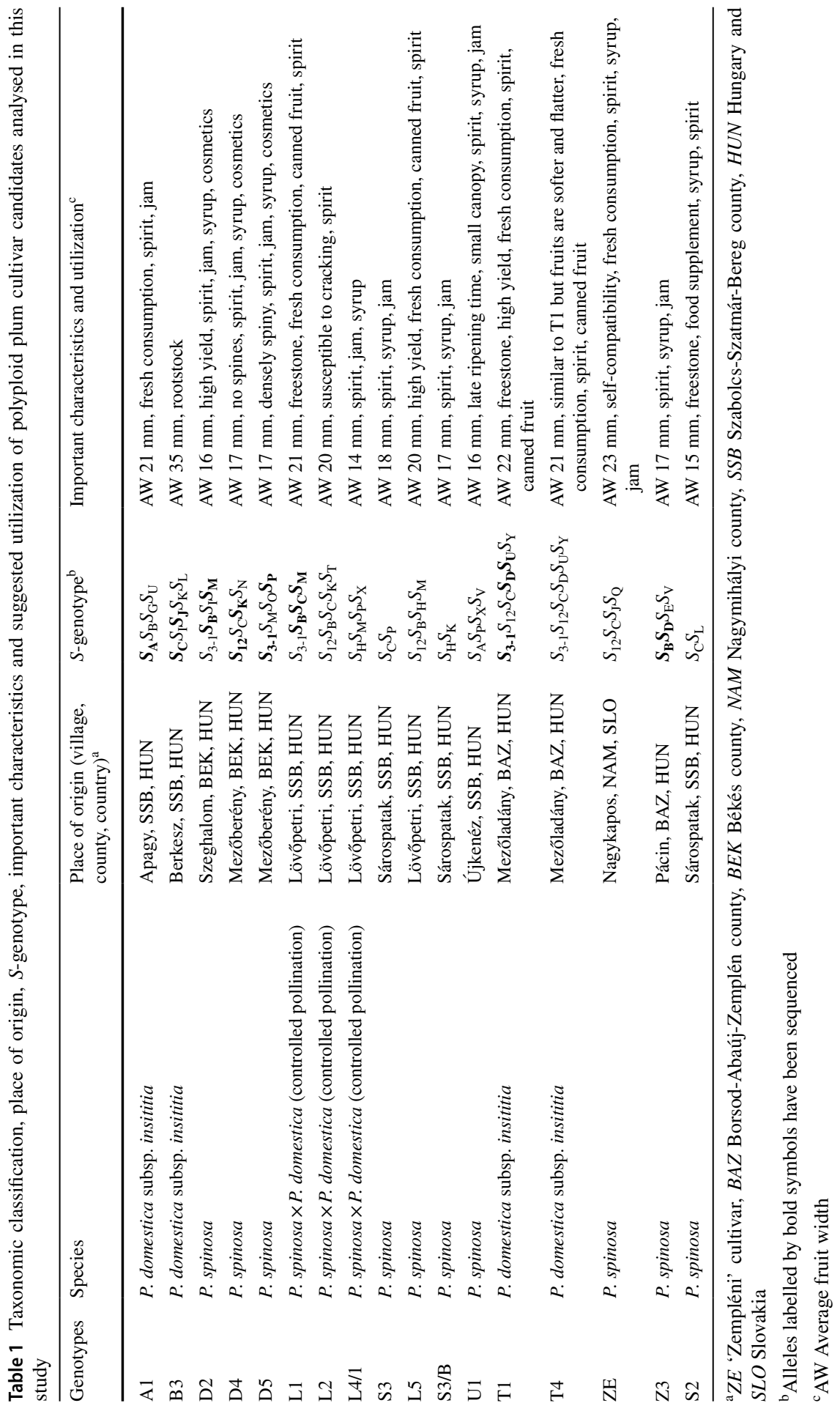


PCR reactions were carried out in a PTC 200 thermocycler (MJ Research, Budapest, Hungary) using the program described for the primers. Approximately 20-80 ng of genomic DNA was used for PCR amplification in a $25 \mu$ l reaction volume containing $10 \times$ DreamTaq ${ }^{\mathrm{TM}}$ Green buffer (Fermentas, Szeged, Hungary) as well as $\mathrm{KCl}$ and $\left(\mathrm{NH}_{4}\right)_{2} \mathrm{SO}_{4}$ at a ratio optimized for robust performance of DreamTaq ${ }^{\mathrm{TM}}$ DNA Polymerase in PCR with final concentrations of $4.5 \mathrm{mM} \mathrm{MgCl}$, $0.2 \mathrm{mM}$ of dNTPs, $0.2 \mu \mathrm{M}$ of the adequate primers and $0.75 \mathrm{U}$ of DreamTaq ${ }^{\mathrm{TM}}$ DNA polymerase (Fermentas).

\section{Cloning and Sequencing}

PCR products were ligated to the TA cloning vector pTZ57R/T (InsTAclone PCR Cloning Kit, Thermo Scientific) and transformed into DH5 $\alpha$ competent Escherichia coli cells. Positive transformants were identified by blue/white selection according to the protocol. Plasmid DNA was isolated with the EZ-10 Spin Column Plasmid DNA kit (Bio Basic Inc., Markham, Canada) and sequenced using an ABI 3500 XL Genetic Analyzer (Applied Biosystems, Foster City. CA, USA). For each fragment, the nucleotide sequences of two clones were determined in both directions with sequencing primer. Homology searches of DNA sequences were carried out using blastn at NCBI and aligned and presented with MEGA5.1 (Tamura et al. 2011) and BioEdit v. 7.2.0. (Hall 1999), respectively.

\section{Allele Sizing and Data Analysis}

To check the PCR amplifications and determine the approximate sizes of the SSR and $S$-RNase first intron alleles, $4 \mu \mathrm{l}$ of the PCR products were separated by electrophoresis in $1.2 \%$ TAE agarose gels for $2 \mathrm{~h}$ at $100 \mathrm{~V}$ and DNA bands were visualized by ethidium bromide staining. The $S$-RNase second intron PCR products were separated in $1.5 \%$ TAE agarose gels for $2 \mathrm{~h}$ at $120 \mathrm{~V}$, and DNA bands were also visualized by ethidium bromide staining. Fragment lengths were estimated by comparison with the GeneRuler 1 kb DNA Ladder (Thermo Fisher Scientific). To determine the exact size of the SSR alleles and S-RNase first intron region, the fluorescently labelled PCR products were run on an automated sequencer ABI PRISM 3100 Genetic Analyzer (Applied Biosystems). Peak Scanner 1.0 software and the GS500 LIZ size standard (Applied Biosystems) were used for determination of size in bp. The polymorphic information content (PIC) of markers was calculated according to Hildebrand et al. (1992).

The evolutionary divergence between sequences was estimated using the Poisson correction model (Zuckerkandl and Pauling 1965). The analysis involved 22 amino acid sequences. All positions containing gaps and missing data were eliminated. There was a total of 123 positions in the final dataset. Evolutionary analyses were conducted in MEGA5.1.

For the phylogenetic analysis, two datasets were used. First, each detected allele from SSR was used separately and then it was completed with $S$-RNase second intron genotyping data. Alleles were scored as present (1) or absent (0). The unweighted 
pair-group average algorithm (UPGMA) was used to construct a dendrogram based on Dice similarity coefficients with the software PAST 2.17c (Hammer et al. 2001). Numbers on major branches represent bootstrap supports from 2000 replicates. Principal component analysis (PCA) was also carried out using PAST software.

\section{Results and Discussion}

\section{SSR Marker Analysis}

In recent years, many studies have dealt with SSR marker development and fingerprinting of Prunus species. In this study, a total of 11 SSR loci were screened using primers designed for different Prunus species and tested for cross-amplification within the Prunus genus (Dirlewanger et al. 2002; Howad et al. 2005; Mnejja et al. 2004, 2005). Loci were chosen based on the detected polymorphism level. Amplification was not successful in some samples in case of CPSCT018 while ASSR63 was monomorphic amplifying a single fragment of $157 \mathrm{bp}$ in each of the samples. Therefore, data of the latter two primers were excluded from the evaluation. The remaining 9 loci proved to be polymorphic (Table 2). The genotyping data for each of the 9 SSR markers presented in Supplementary Table 1 are readily available. In each genotype, 1-6 alleles were detected according to the different ploidy levels of accessions. As expected, the presumable tetraploid, pentaploid and hexaploid genotypes amplified maximum 4, 5 and 6 alleles in each locus, respectively. In cases when the number of detected alleles was lower than the expected number, we hypothesized the presence of null alleles or that one or two of the alleles were present in more copies.

SSR genotyping of polyploids might be challenging (Mason 2015). However, the tested primers provided clear amplification and reliable allele identification was not even hindered by stuttering (representative chromatograms are shown in Supplementary Fig. 2). A total of 129 different SSR alleles were identified, which means 14.3 average allele number per locus ranging from 5 (BPPCT037) to 26 (CPSCT021). Seven of the markers used in this study were also included in genotyping 53 hexaploid $P$. domestica accessions and amplified a similar number of alleles. The biggest difference in amplified allele number was seen in case of BPPCT039 that produced many more alleles in the hexaploid samples (Makovics-Zsohár et al. 2017; Urrestarazu et al. 2018). Horvath et al. (2011) also used the BPPCT007 primers and found 19 alleles (122-160 bp) in 14 blackthorn genotypes. Those numbers are very similar to the ones obtained in the present study (17 alleles, 122-154 bp). They detected 32 alleles in the BPPCT025 loci, which exceeds the allele number (25) in this locus of the analysed Hungarian accessions. The CPSCT021 marker was analysed in 8 Japanese plums (Mnejja et al. 2004) and in function of the smaller sample set, the detected number of alleles (4) and size range was smaller than in this study. Primers for the CPDCT044 almond locus worked properly also in Japanese plums and amplified a total of 7 alleles in eight almond cultivars (Mnejja et al. 2005), while 3.4-times more alleles were identified in the tested 17 polyploid Prunus genotypes presumably due to their enhanced ploidy level. 


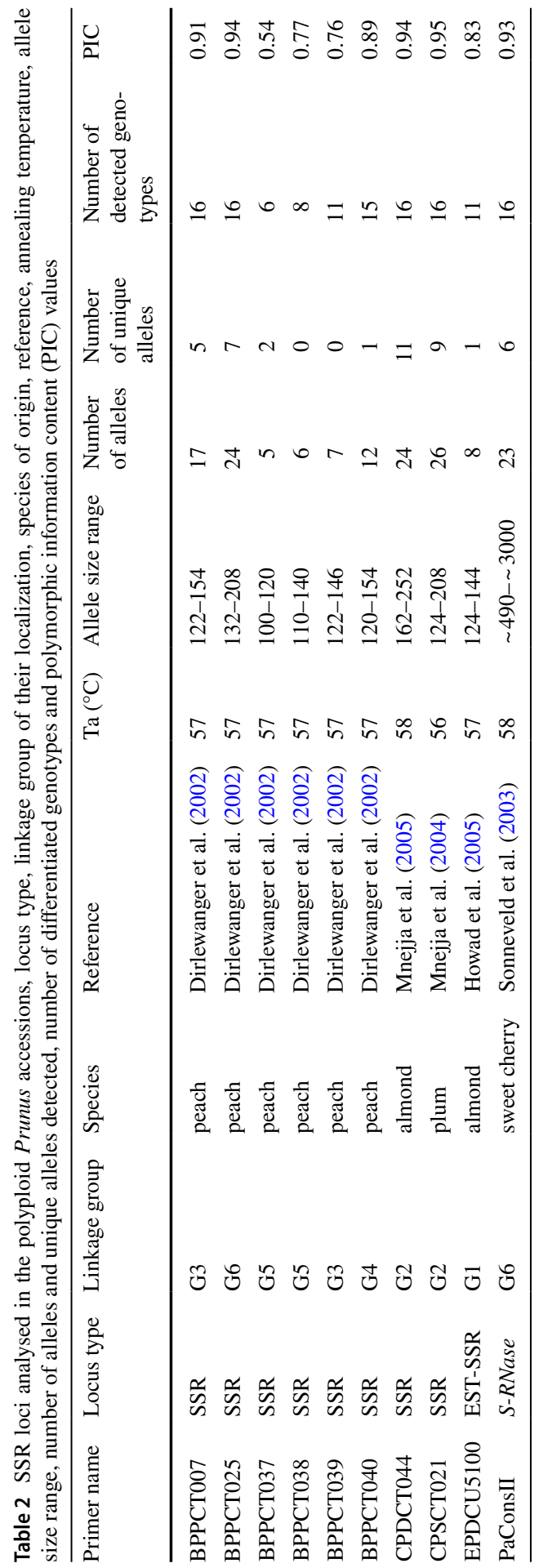


Among 11 SSR markers, BPPCT037 proved to be the most informative primer in P. lannesiana and amplified five-times more alleles than in this study (Kato et al. 2011). In the tetraploid P. cerasus it amplified 16 alleles, which exceeded the number of amplified alleles for other loci including BPPCT007, ВРPCT038, ВРPCT039 and BPPCT040 (Antonius et al. 2012). Considering that those latter primer pairs amplified almost identical (BPCCT038 and BPPCT039) or larger numbers of alleles (BPPCT007 and BPPCT040) in polyploid plums and sour cherry, the limited performance of BPPCT037 is not explained by the smaller number of samples or differences in ploidy level. It indicates that levels of allelic variability in SSR loci can vary species by species and BPPCT037 is more polymorphic in Prunus species of the Cerasus subgenus compared to those in Prunophora. The most alleles were amplified by CPSCT021 in our study while this marker was less polymorphic in diploid Prunus species (Mnejja et al. 2010).

The EPDCU5100 locus amplified only two to four alleles in cherry, peach, apricot and almond (Mnejja et al. 2010; Halász et al. 2019); however, in this study we detected a higher number (8) of alleles. Interestingly, Zhang et al. (2014) also detected 8 alleles in the EPDCU5100 locus by analysing 94 Chinese apricot accessions. Although this marker is characterized by lower polymorphism compared to others used in this study (e.g. CPSCT021 or BPPCT025), it amplifies enough alleles to be efficiently used in a diverse sample set like polyploid Prunus accessions.

Allele sizes varied from 100 to $252 \mathrm{bp}$. The highest size range was caught in the CPDCT044 locus (a difference of $90 \mathrm{bp}$ ), while the lowest range was shown in BPPCT037 and EPDCU5100 (20 bp in both cases). Since wide discrepancies were detected in the number of amplified alleles, the polymorphic information content of loci changed accordingly, ranging from 0.54 (BPPCT037) to 0.95 (CPSCT021). The average PIC value was 0.84 . This is much higher than PIC values of SSR markers in other tetraploid species including cotton and coffee (Lacape et al. 2007; Moncada and McCouch 2004) and slightly higher than 0.73 for P. serotina (Guzmán et al. 2018) and identical to the value obtained for sour cherry (Lacis et al. 2011). A PIC value exceeding 0.7 is considered to be highly informative (Hildebrand et al. 1992) indicating that 8 of the applied 9 SSR markers used in this study have great potential for molecular studies in polyploid Prunus species. The lowest PIC value was also higher than 0.44 that is considered to be the threshold for moderately informative markers.

The CPDCT044 locus had the most unique alleles (11), while loci with limited allele numbers and PIC values (BPPCT038 and BPPCT039) had not produced alleles occurring exclusively in a given genotype. It is interesting to realize that the least informative locus, BPPCT037, had amplified two alleles exclusively occurring in a single genotype, one of those in S2 and another in 'Zempléni' (Supplementary Table 1).

The genotypes carrying a maximum of 4 alleles in the analysed loci, are likely to be tetraploids (D2, D4, D5, L5, S2, S3, S3/B, U1, Z3 and 'Zempléni'), while a genotype characterized by 5 alleles in at least one locus (e.g. L1 in BPPCT007) is consistent with the notion that it is a pentaploid hybrid of $P$. spinos $a \times P$. domestica. The fact that L2 or L4/1 amplified only 1-4 alleles in each locus cannot rule out its supposed pentaploid genome as they are artificial hybrids of a tetraploid P. spinosa 
and hexaploid $P$. domestica. We also had four $P$. domestica subsp. insititia accessions with a presumable hexaploid genome structure. However, only 1-5 alleles were amplified in three of the four accessions and only B3 had six alleles in the CPPCT044 locus. The same range of alleles was amplified in hexaploid P. domestica subsp. insititia by Wünsch (2009) indicating that ploidy level cannot be assessed based on SSR data since the absence of alleles (due to deletion of the corresponding genomic regions) or their presence in multiple copies may not allow the determination of the copy number of alleles. Therefore, cytological or flow cytometry analyses are needed to unequivocally determine ploidy levels (Halász et al. 2011).

The polymorphism detected in the tested loci is in agreement with the resolution power of the markers since all SSR primers characterized by PIC values higher than 0.90 were able to discriminate 16 genotypes of the 17 accessions tested. One pair of $P$. domestica subsp. insititia accessions (T1 and T4) produced identical genotypes by using all 9 markers and could be identified as putative clones (see later). It means that using a single marker out of the four markers with higher than 0.9 PIC values allowed the discrimination of the polyploid Prunus accessions tested in this study. Similarly, a combination of only two markers with lower PIC values, BPPCT039 and EPDCU5100 might be enough to differentiate polyploid Prunus genotypes. Such high levels of genetic variability are common in case of self-incompatible, generatively propagated species (Kodad et al. 2013), and useful markers were identified for the genetic analysis of polyploid plums.

\section{S-allele Profiling}

P. spinosa is a self-incompatible (SI) species, and its sexual incompatibility is governed by the highly polymorphic $S$-locus (Nunes et al. 2006). Since under a functional SI system, homozygosity is impossible in the $S$-locus, this polymorphism might be also exploited for the estimation of genetic variation. Until now, only two works dealt with the analysis of $S$-locus in wild blackthorn individuals (Nunes et al. 2006; Vieira et al. 2008). However, P. domestica has both self-incompatible and self-compatible cultivars (Kota-Dombrovska and Lacis 2013) and its hexaploidy genome further increases the allelic diversity at the $S$-locus. This is the first study to determine the $S$-allele constitution of Central European blackthorn genotypes and to test its application for genetic studies.

For $S$-allele profiling in Prunus genus, the ILP technique based on the pistilexpressed $S$-RNase gene is the most common method (Sonneveld et al. 2003). We used the PaConsI-F/PaConsIR2 (Sonneveld et al. 2003, 2006) and PaConsII-F/ PaConsII-R (Sonneveld et al. 2003) primer pairs designed to amplify the first and second intron region of the gene, respectively. The amplification of first intron region did not produce fragments of acceptable intensity in case of A1, D4, L2, S2 and S3/B samples and resulted in only partial amplification for the others with 1 to 4 fragments of putative $S$-alleles. A total of 36 fragments were amplified for 17 accessions, an average of 2.1 alleles per accession. The PaConsII primer pair proved to give the most informative banding pattern with 68 fragments across the 17 accessions resulting in an average of 4 alleles per genotype. Amplified fragment 


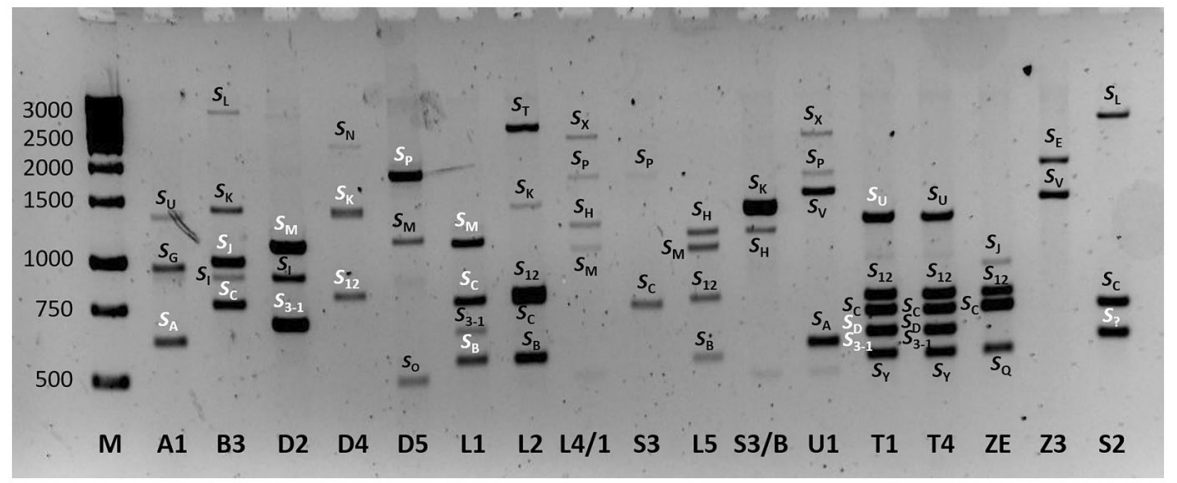

Fig. 1 Polymerase chain reaction (PCR) analysis of the second intron region of self-incompatibility ribonuclease (S-RNase) alleles in 17 polyploid Prunus accessions using the PaConsII primer pair. Lane M, $1-\mathrm{kb}+$ ladder; accessions are identified with their labels as mentioned in Table 1. The alleles determined by DNA sequencing are indicated by white characters. S? refers to an allele which requires further study to identified

sizes ranged from $490 \mathrm{bp}$ to $3000 \mathrm{bp}$ (Fig. 1, Table 2). The statistics reflecting the diversity in $S$-locus and BPPCT025 SSR locus are in good agreement. These loci are in proximity on the Prunus linkage group 6; therefore, similar allelic variation is expected. The different fragment lengths were assigned to self-incompatibility alleles, provisionally labelled by letters $\left(S_{\mathrm{A}}-S_{\mathrm{Y}}\right)$.

To check the amplified fragments indeed code for $S$-RNase alleles, some PCR products of the tetraploid $P$. spinosa D2, D4, D5 and Z3, the pentaploid $P$. spinosa $\times P$. domestica hybrid L1 and the hexaploid $P$. domestica subsp. insititia A1, $\mathrm{B} 3$ and $\mathrm{T} 1$ were cloned and sequenced. Although the size variations of the second intron regions occurring within the range of 2,500 bp length allowed the reliable identification for most of the alleles, there were pairs of alleles with almost identical fragment sizes (e.g. $S_{3-1}$ and $S_{\mathrm{D}}$ ). DNA sequencing was also required to discriminate such alleles since some genotypes (T1 and T4) carried both alleles while only a single band could be observed on gels (Fig. 1). It also explains why the allele represented by an approx. 700-bp fragment in S2 accession is yet to be identified.

The DNA sequence was determined for a total of 17 fragments representing 11 $S$-RNase alleles of 8 accessions. The sequences were deposited in the DDBJ/EMBL/ GenBank databases under the following accession numbers, MN052897-MN052899 and MN069629-MN069642. Homology searches undoubtedly declared that all fragments were homologous to the Prunus self-incompatibility ribonuclease gene (Supplementary Table 2).

The alignment of the deduced amino acids from $\mathrm{C} 2$ to $\mathrm{C} 5$ of the 10 polyploid Prunus S-RNase alleles identified in this study and 12 P. spinosa S-RNase sequences available in database (determined by Nunes et al. 2006 and Vieira et al. 2007 ) is shown in Fig. 2. The conserved regions and the RHV are shown according to Ushijima et al. (1998) and the position of the S-RNase second intron found within the RHV region is also indicated. Variable amino acid positions and conserved amino acid replacements are marked by black and grey background colours, 


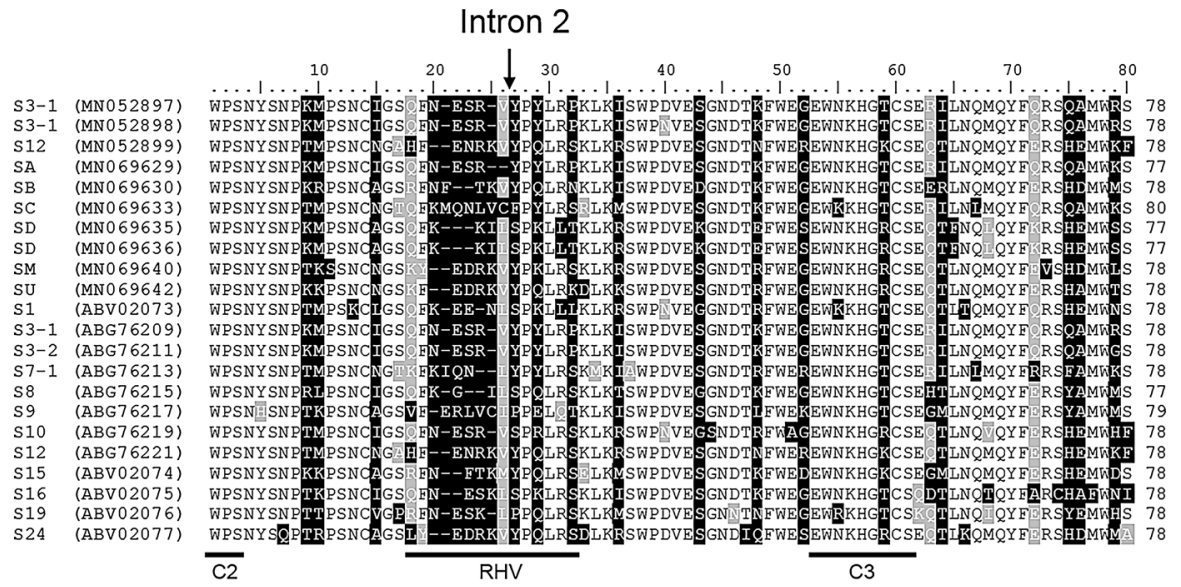

$\begin{array}{ll}\text { S3-1 } & \text { (MN052897) } \\ \text { S3-1 } & \text { (MN052898) } \\ \text { S12 } & \text { (MN052899) } \\ \text { SA } & \text { (MN069629) } \\ \text { SB } & \text { (MN06963) } \\ \text { SC } & (\text { MN069633) } \\ \text { SD } & \text { (MN069635) } \\ \text { SD } & \text { (MN069636) } \\ \text { SM } & (\text { MN069640) } \\ \text { SU } & \text { (MN069642) } \\ \text { S1 } & \text { (ABV02073) } \\ \text { S3-1 } & \text { (ABG76209) } \\ \text { S3-2 } & \text { (ABG76211) } \\ \text { S7-1 } & \text { (ABG76213) } \\ \text { S8 } & \text { (ABG76215) } \\ \text { S9 } & \text { (ABG76217) } \\ \text { S10 } & \text { (ABG76219) } \\ \text { S12 } & \text { (ABG76221) } \\ \text { S15 } & \text { (ABV02074) } \\ \text { S16 } & \text { (ABV02075) } \\ \text { S19 } & \text { (ABV02076) } \\ \text { S24 } & \text { (ABV02077) }\end{array}$

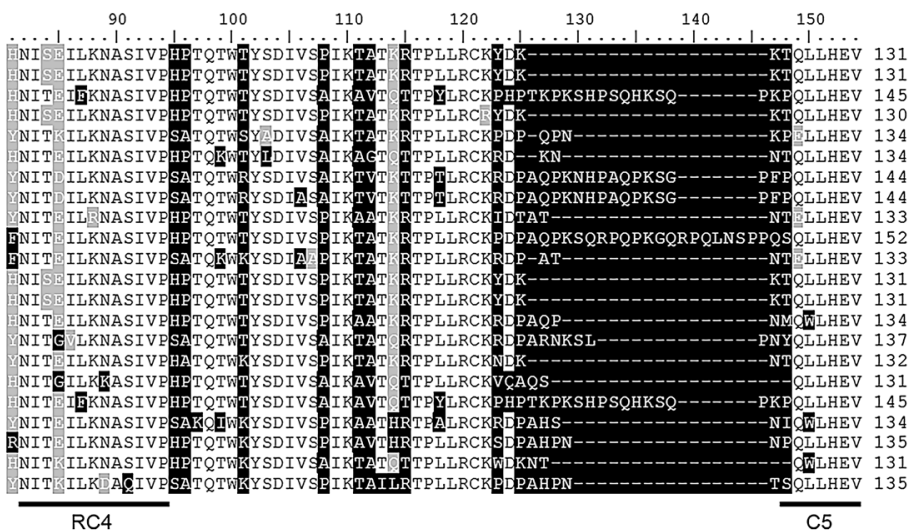

Fig. 2 Multiple alignment of 10 deduced amino acid sequences of the polyploid Prunus S-RNase alleles identified in this study and 12 Prunus spinosa S-RNase sequences available in GenBank database. The conserved regions (C2-C5) and the hypervariable region (RHV) are underlined according to Ushijima et al. (1998). The arrow indicates the position of the second intron

respectively. The identified sequences show the characteristic structural motifs of Prunus S-RNase enzymes with C2-C5 conserved regions and two highly variable motifs (including the RHV and the region between RC4 and C5). The blastn analysis, the alignment and the estimates of divergence between sequences (Supplementary Table 3) indicated that both T1 and D5 carry an S-RNase-allele identical to that described by Nunes et al. (2006) as $S_{3-1}$. Another allele in D4 proved to be identical to $S_{12}$ described by the same authors in Portuguese wild-growing $P$. spinosa populations.

We have cloned and sequenced certain $S$-RNase alleles from different genotypes (Supplementary Table 2). D2, L1 and Z3 had the $S_{\mathrm{B}}$-allele, all of which are identical to each other. One copy of $S_{\mathrm{C}}$ and $S_{\mathrm{M}}$ sequences was slightly shorter ending just before the $\mathrm{C} 5$ region; and hence those sequences were not included in the alignment. 
However, the two copies of the allele $S_{3-1}$ (identified in T1 and D5 genotypes), and $S_{\mathrm{D}}$ (carried by $\mathrm{T} 1$ and $\mathrm{Z} 3$ ) showed minor polymorphisms. The $S_{3-1}$ sequences differed in two and four bases in the intron and exon regions of the gene, respectively; that resulted in a single non-synonymous amino acid replacement $(\mathrm{D} \rightarrow \mathrm{N})$ in the third exon. The two sequenced $S_{\mathrm{D}}$-alleles differed in only one base resulting in a non-synonymous amino acid replacement $(\mathrm{V} \rightarrow \mathrm{A})$ between the RC4 and $\mathrm{C} 5$ regions. Considering the positions of such intra-allelic variations in the alleles $S_{3-1}$ and $S_{\mathrm{D}}$ are outside the most variable regions of the gene that have a confirmed role in determining allele-specificity (Matton et al. 1997; Ortega et al. 2006; Ushijima et al. 1998), they are not expected to change allele specificity, although controlled pollination would be required to clarify it.

The sequence analysis of $S_{\mathrm{J}}$-allele cloned from B3 revealed the presence of a premature stop codon (AAA $\rightarrow$ TAA) in the last amino acid position of the RHV region. Consequently, the transcript of the gene is supposed to encode a truncated protein lacking a large 3' segment of the third exon of S-RNase gene including the His amino acid within the $\mathrm{C} 3$ conserved region that is thought to be involved in enzyme catalysis (Broothaerts et al. 1995). Hence, $S_{\mathrm{J}}$-RNase is supposed to be nonfunctional. $S_{\mathrm{J}}$ is also carried by cultivar 'Zempléni' that has been characterized by autogamous fruit set ratios in isolated flowers ranging from 12 to $26 \%$ over three years, confirming this cultivar to be self-compatible (SC). Artificial field pollination experiments have not revealed self-compatible (SC) $P$. spinosa genotypes in Portugal (Nunes et al. 2006) but polyploid Prunus species (e.g. tetraploid sour cherry) generally include both self-compatible and self-incompatible genotypes (Hauck et al. 2006; Hegedús et al. 2012), and hence the occurrence of SC blackthorn genotypes cannot be ruled out. 'Zempléni' is the first blackthorn cultivar that had received state recognition in Hungary, and self-compatibility would be a preferred character in cultivation. However, further analysis (e.g. sequencing the pollen $S F B$ alleles) is required to clarify the molecular basis of SC in 'Zempléni'; since self-compatibility in sour cherry, another allotetraploid species is induced by the accumulation of at least two non-functional $S$-haplotypes (Hauck et al. 2006).

A total of $23 S$-RNase alleles were identified in 17 tested polyploid Prunus genotypes with six unique alleles found only in a single genotype. In conclusion, the PIC value of PaConsII primer pair reached the values characteristic for the most efficient SSR markers. Only two P. domestica subsp. insititia accessions (T1 and T4) shared a common $S$-genotype. They also had identical SSR profiles in all tested loci. Both accessions derived from the same region but far enough (4 km apart) to exclude that vegetatively spreading runners had been sampled. In addition, they presented slight phenotypic variations presumably derived from bud sport mutations occurred during clonal propagation. Grafting has been long used in countryside to propagate perspective individuals. It is important to remark that such accessions cannot fertilize each other when planted in a common orchard.

The $S$-genotypes are consistent with the taxonomic classification of the studied accessions. As in case of SSR analysis, the three presumed ploidy levels $(4 \times$, $5 \times$ and $6 \times$ ) resulted in different allele numbers in the analysed accessions. The largest $S$-allele number (6) was detected in T1 and T4 $P$. domestica subsp. insititia accessions. The smallest allele number (2) was recorded in S3 and S3/B genotypes. 
Ten accessions had four $S$-alleles (A1, D2, D4, D5, L1, L4/1, L5, U1, Z3 and 'Zempléni' cultivar) (Table 1). Two genotypes (B3 and L2) carried 5 alleles. B3 is a presumable hexaploid $P$. domestica subsp. insititia and L2 is a putative pentaploid hybrid arisen from a controlled cross of $P$. spinosa and $P$. domestica. The detection of fewer $S$-RNase alleles than expected can be explained by several reasons including the preferential amplification of specific alleles in consensus PCR (Walsh et al. 1992; Kota-Dombrovska and Lacis 2013), the matching sizes of amplicons representing different alleles (Kodad et al. 2008), the presence of null alleles or the multiple appearance of a given allele in the $S$-locus (Pairon et al. 2008; Tsukamoto et al. 2010). However, the presence of multiple copies of an $S$-allele is only possible in case of non-functional alleles. Moncada and McCouch (2004) measured a significant drop in the allele numbers and PIC values of the markers used for fingerprinting cultivated tetraploid coffee compared to the diploid Coffea species. It was explained by the facts that diploids are outcrossing and come from diverse geographical origins, while the tetraploids are predominantly self-pollinating, and all originated from Ethiopia. The high allele numbers and PIC values in the studied polyploid Prunus germplasm are consistent with the notion of self-incompatibility for most accessions. The great number of $S$-alleles in a self-incompatible species is normal since the number of $S$-alleles often exceeds 40, like in case of almond and apple (Kodad et al. 2008; Halász et al. 2011). In addition, the allo-polyploid genome structure in itself promotes the emergence of new alleles (Ainouche et al. 2014).

$S_{\mathrm{C}}$ was the most frequent $S$-RNase allele carried by 9 accessions, each $S_{12}$ and $S_{\mathrm{B}}$ was carried by 6 , and $S_{3-1}$ by 5 accessions (Table 3 ). Interestingly, both $S_{3-1}$ and $S_{12^{-}}$ alleles were also found in three of the 11 tested Portuguese wild-growing blackthorn individuals (Nunes et al. 2006). It indicates these alleles are quite frequent in blackthorn accessions growing in distant geographic positions. From $23 S$-RNase alleles, ten and two alleles were specific to tetraploid $P$. spinosa and hexaploid $P$. domestica, respectively, while 11 were carried by both species. It indicates that the $S$-allele pools of $P$. spinosa and $P$. domestica subsp. insititia are overlapping in Hungary. The $S_{\mathrm{T}}$-allele occurred only in a $P$. spinosa $\times P$. domestica hybrid and hence its origin remains unknown. Currently, only three $P$. domestica $S$-RNase allele sequences are known (Sutherland et al. 2008), all of which seem to be different from $S_{\mathrm{G}}$ and $S_{\mathrm{U}}$ based on the length of second intron regions. Sequencing and a more detailed analysis of $S$-alleles in hexaploid European plum will be required to clarify those alleles.

In cultivated self-incompatible species, it is a crucial point to check sexual compatibility because it determines reliable fruit set. Cultivars carrying different $S$-alleles (belonging to different cross-incompatibility groups) must be inter-planted in orchards; therefore, the information of $S$-genotypes is necessary for both growing and breeding (Yamane and Tao 2009). Using the ILP marker strategy, complete or partial $S$-genotypes of cultivar candidates were determined (Table 1). Altogether 10 complete $S$-genotypes were identified, and only two accessions (putative clones) shared identical alleles (T1 and T4). Since all other cultivar candidates had different $S$-allele compositions, it makes them potential pollen donors in any combinations. However, polyploidy may limit pollen fertility. Similarly to P. cerasus, blackthorn is considered to have equal chance for all possible chromosome pairing during meiosis (Vieira et al. 2008). In such a case, when two tetraploid accessions sharing two 
Table 3 Approximate and precise allele sizes (bp) based on the estimation from agarose gel pattern of the PCR fragments amplified using the PaConsII primers (Sonneveld et al. 2003) and DNA sequencing, respectively, allele frequencies and occurrences in the tested species

\begin{tabular}{|c|c|c|c|c|c|c|}
\hline \multirow[t]{2}{*}{ Allele } & \multirow[t]{2}{*}{ Size (bp) } & \multirow[t]{2}{*}{ Frequency } & \multicolumn{4}{|c|}{ Occurrences $^{\mathrm{a}}$} \\
\hline & & & $P s$ & $P i$ & $P s \times P d$ & Total \\
\hline$S_{3-1}$ & 713 & 6.33 & 2 & 2 & 1 & 5 \\
\hline$S_{12}$ & 815 & 7.59 & 3 & 2 & 1 & 6 \\
\hline$S_{\mathrm{A}}$ & 627 & 2.53 & 1 & 1 & 0 & 2 \\
\hline$S_{\mathrm{B}}$ & 559 & 7.59 & 3 & 1 & 2 & 6 \\
\hline$S_{\mathrm{C}}$ & 783 & 11.39 & 4 & 3 & 2 & 9 \\
\hline$S_{\mathrm{D}}$ & 716 & 3.80 & 1 & 2 & 0 & 3 \\
\hline$S_{\mathrm{E}}$ & $\sim 2100$ & 1.27 & 1 & 0 & 0 & 1 \\
\hline$S_{\mathrm{G}}$ & $\sim 980$ & 1.27 & 0 & 1 & 0 & 1 \\
\hline$S_{\mathrm{H}}$ & $\sim 1250$ & 3.80 & 2 & 0 & 1 & 3 \\
\hline$S_{\mathrm{I}}$ & $\sim 950$ & 2.53 & 1 & 1 & 0 & 2 \\
\hline$S_{\mathrm{J}}$ & 1013 & 2.53 & 1 & 1 & 0 & 2 \\
\hline$S_{\mathrm{K}}$ & $\sim 1450$ & 5.06 & 2 & 1 & 1 & 4 \\
\hline$S_{\mathrm{L}}$ & $\sim 3000$ & 2.53 & 1 & 1 & 0 & 2 \\
\hline$S_{\mathrm{M}}$ & 1113 & 6.33 & 3 & 0 & 2 & 5 \\
\hline$S_{\mathrm{N}}$ & $\sim 2500$ & 1.27 & 1 & 0 & 0 & 1 \\
\hline$S_{\mathrm{O}}$ & $\sim 490$ & 1.27 & 1 & 0 & 0 & 1 \\
\hline$S_{\mathrm{P}}$ & $\sim 1800$ & 5.06 & 3 & 0 & 1 & 4 \\
\hline$S_{\mathrm{Q}}$ & $\sim 610$ & 1.27 & 1 & 0 & 0 & 1 \\
\hline$S_{\mathrm{T}}$ & $\sim 2700$ & 1.27 & 0 & 0 & 1 & 1 \\
\hline$S_{\mathrm{U}}$ & $\sim 1400$ & 3.80 & 1 & 2 & 0 & 3 \\
\hline$S_{\mathrm{V}}$ & $\sim 1500$ & 2.53 & 2 & 0 & 0 & 2 \\
\hline$S_{\mathrm{X}}$ & $\sim 2600$ & 2.53 & 1 & 0 & 1 & 2 \\
\hline$S_{\mathrm{Y}}$ & $\sim 590$ & 2.53 & 0 & 2 & 0 & 2 \\
\hline
\end{tabular}

${ }^{a}$ Ps Prunus spinosa, Pi P. domestica subsp. insititia, Ps $\times$ Pd P. spinosa $\times$ P. domestica hybrids

$S$-alleles (e.g. D2 $\times$ D5 or D4× 'Zempléni') are crossed, less than $20 \%$ of the pollen grains (those carrying no matching alleles with the plant to be pollinated) will be able to grow in the pistil to the ovary. It may seriously limit the amount of compatible pollen grains and decrease fruit set.

\section{Estimation of Genetic Distances}

Altogether 429 alleles amplified in nine SSR loci of 17 cultivar candidates were used to estimate the genetic distance and perform UPGMA cluster analysis based on Dice indices (Fig. 3). The cophenetic correlation value of the dendrogram was 0.81 , indicating a quite good fit that was statistically significant at the $1 \%$ level according to Lapointe and Legendre (1992). The dendrogram grouped the accessions into four sub-clusters, two of which contained only $P$. spinosa accessions, another group consisted of $P$. spinosa and its hybrids while the fourth clade grouped $P$. domestica subsp. insititia and $P$. spinosa accessions. A similar co-clustering of some $P$. spinosa 
Fig. 3 Unweighted pair-group average (UPGMA) dendrogram based on Dice indices among SSR genotypes in 9 loci of 17 native Prunus spinosa (squares), $P$. domestica subsp. insititia (asterisks) and $P$. spinosa $\times P$. domestica hybrid (hexagons) accessions. Numbers indicate bootstrap values (percentage of 2000 replicates). Bootstrap values greater than $50 \%$ are shown

and $P$. domestica subsp. insititia genotypes was also observed using sequence-based genotyping (Zhebentyayeva et al. 2019).

All $P$. domestica subsp. insititia genotypes grouped together (A1, B3, T1 and T4) with strong bootstrap support. T1 and T4 were identical. Two interspecific ( $P$. spinosa $\times P$. domestica) hybrids (L1 and L2) were close to each other and formed a common clade with a $P$. spinosa genotype (L5), which received strong bootstrap support. Another hybrid, L4/1 was also positioned in this clade. The phylogenetic analysis suggests that L5 was a progenitor genotype for the studied hybrids. Such a relationship is further supported by the $S$-genotypes, since L5 shared two $S$-alleles with each of the three hybrids (L1, L2 and L4/1).

The cluster analysis was also carried out on the merged dataset of SSR and $S$-genotype markers by incorporating the distribution pattern of 68 detected $S$-RNase fragments among the 17 tested accessions. The basic structure of the dendrogram remained unchanged; however, the position of some accessions changed considerably (Supplementary Fig. 3). For example, 'Zempléni' cultivar and Z3 formed a sister clade to the $P$. domestica subsp. insititia clade in SSR genotyping, while the inclusion of $S$-genotypes placed 'Zempléni' cultivar within this clade together with hexaploid accessions. This is obviously not correct and presents a warning signal that $S$-locus information might not be useful for phylogenetic analysis. 'Zempléni' shares two $S$-alleles with B3 $\left(S_{\mathrm{C}}\right.$ and $\left.S_{\mathrm{J}}\right)$ and with T1-T4 $\left(S_{12} S_{\mathrm{C}}\right)$. Since 'Zempléni' is $P$. spinosa while the rest are $P$. domestica subsp. insititia, matching $S$-alleles must be the consequence of chance effects rather than phylogenetic relationships. In loquat, pairs of cultivars (e.g. 'Mogi' and 'Alcácer', 'Wanzhong' and 'Mc Beth') with identical $S$-genotypes were confirmed to be distantly related (Gisbert et al. 2009). Similar results were obtained for sweet cherry (Wünsch and Hormaza 2002) and almond (Halász et al. 2019) cultivars.

PCA analysis confirmed the information provided by the dendrogram and supplied further details. The first two principal axes accounted for $18.8 \%$ and $10.2 \%$ of the total variation. PCA analysis confirmed that the hexaploid T1 and T4 genotypes were identical in SSR genotypes and it revealed their great genetic distance from the rest of the tested accessions (Fig. 4). The two additional $P$. domestica subsp. insititia A1 and B3 accessions are also placed close together and into a different position from $P$. spinosa. Interestingly, PC2 could only slightly differentiate among two pairs of hexaploid plums (T1-T4 and A1-B3). The first two principal components sharply separated the $P$. spinos $a \times P$. domestica hybrids and their presumable progenitor $P$. spinosa accession, L5, from the rest of the studied genotypes. PCA was efficiently used for plum diversity studies based on both phenotyping and genotyping (Horvath et al. 2011; Yilmaz et al. 2009). The phylogenetic analysis and PCA plot confirmed a high level of diversity and genetic differentiation present within the analysed genotypes and supported putative ancestor-descendant relationships for some accessions. 
Similarity

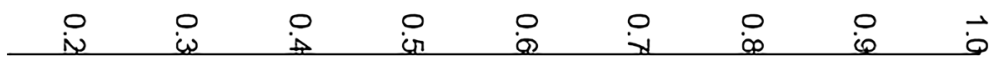

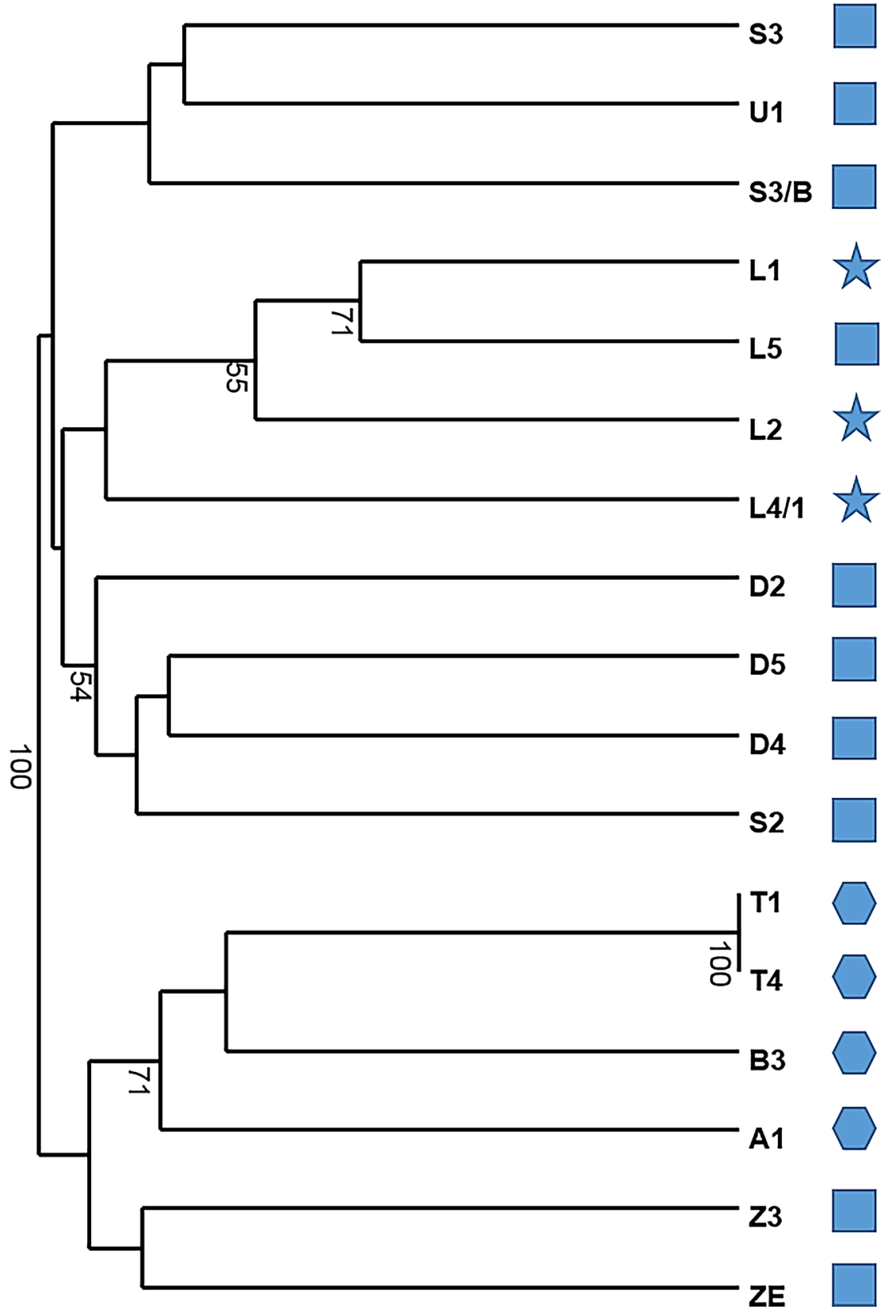




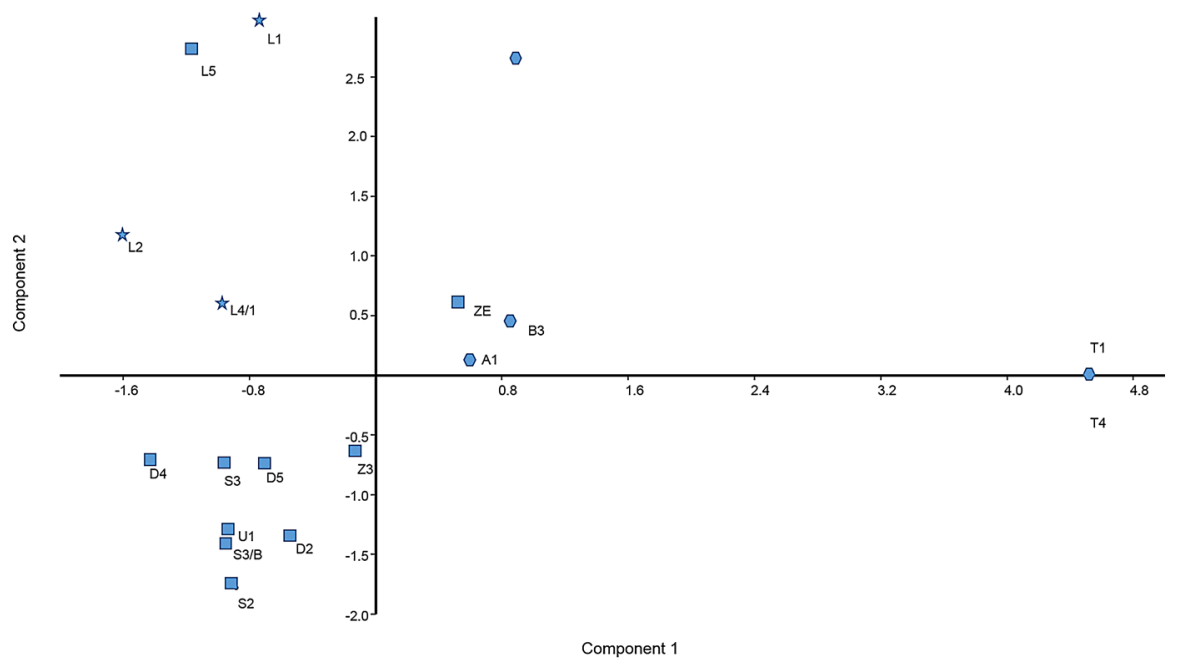

Fig. 4 Distribution of Prunus spinosa, P. domestica subsp. insititia and P. spinosa $\times P$. domestica cultivar candidates on the two first principal component analysis axes determined from SSR genotyping

\section{Conclusions}

High genetic diversity was observed among 17 polyploid plum accessions (P. spinosa, $P$. domestica subsp. insititia and $P$. spinosa $\times P$. domestica hybrid cultivar candidates) in Hungary using both SSR and $S$-locus based genotyping. Eight of the applied 9 SSR markers used in this study had great potential for molecular studies in polyploid Prunus species with CPSCT021 being the most polymorphic. The multiallelic $S$-locus also provided considerable variability that can be exploited for molecular fingerprinting and diversity studies (it is important for breeding and cultivation); however, phylogenetic analysis may be confused by not related accessions sharing common $S$-alleles. A total of $23 S$-RNase alleles were identified in 17 tested polyploid Prunus accessions, partial DNA sequences were determined for 11 of those. The cultivar 'Zempléni' was found to be selfcompatible and one of its $S$-RNase alleles $\left(S_{\mathrm{J}}\right)$ was determined to contain a premature stop codon and hence it is suggested to be non-functional. It makes the tetraploid $P$. spinosa an important plant species to test general validity of the 'one-allele match' model of self-compatibility in sour cherry described by Hauck et al. (2006). Comparing the results from the phylogenetic clustering and PCA analysis, the taxonomic status of the accessions could be confirmed, and progenitor genotypes could be proposed in some cases. Most of these genotypes were selected from wild populations, which means they represent part of the genetic variations of wild-growing Hungarian blackthorn and P. domestica subsp. insititia species. It confirms that Hungary has rich genetic potential for the exploitation and valorisation of currently under-utilized polyploid plum species. 
Supplementary Information The online version contains supplementary material available at https://doi. org/10.1007/s10528-021-10090-7.

Acknowledgements This work was funded by the National Research, Development and Innovation Office (OTKA) K 112554 and K 128874 projects. J. Halász is grateful for receiving the János Bolyai Research Scholarship of the Hungarian Academy of Sciences. Note: Nucleotide sequence data reported are available in the DDBJ/EMBL/GenBank databases under the accession numbers MN052897-MN052899 and MN069629-MN069642.

Funding Open access funding provided by Hungarian University of Agriculture and Life Sciences.

Open Access This article is licensed under a Creative Commons Attribution 4.0 International License, which permits use, sharing, adaptation, distribution and reproduction in any medium or format, as long as you give appropriate credit to the original author(s) and the source, provide a link to the Creative Commons licence, and indicate if changes were made. The images or other third party material in this article are included in the article's Creative Commons licence, unless indicated otherwise in a credit line to the material. If material is not included in the article's Creative Commons licence and your intended use is not permitted by statutory regulation or exceeds the permitted use, you will need to obtain permission directly from the copyright holder. To view a copy of this licence, visit http://creativecommons.org/licen ses/by/4.0/.

\section{References}

Abdallah D, Baraket G, Perez V, Ben Mustapha S, Salhi-Hannachi A, Hormaza JI (2019) Analysis of self-incompatibility and genetic diversity in diploid and hexaploid plum genotypes. Front Plant Sci 10:896

Ainouche ML, Wendel JF (2014) Polyploid speciation and genome evolution: Lessons from recent allopolyploids. In: Pontarotti P (ed) Evolutionary biology: genome evolution, speciation, coevolution and origin of life. Springer, Cham, pp 87-113

Antonius K, Aaltonen M, Uosukainen M, Hurme T (2012) Genotypic and phenotypic diversity in Finnish cultivated sour cherry (Prunus cerasus L.). Genet Resour Crop Ev 59:375-388

Bailey LH (1925) The standard encyclopedia of horticulture. Macmillan, New York

Broothaerts W, Janssens GA, Proost P, Broekaert WF (1995) cDNA cloning and molecular analysis of two self-incompatibility alleles from apple. Plant Mol Biol 27(3):499-511

Chin SW, Shaw J, Haberle R, Wen J, Potter D (2014) Diversification of almonds, peaches, plums and cherries: molecular systematics and biogeographic history of Prunus (Rosaceae). Mol Phylogenet Evol 76:34-48

Cipriani G, Lot G, Huang WG, Marrazzo MT, Peterlunger E, Testolin R (1999) AC/GT and AG/CT microsatellite repeats in peach [Prunus persica (L) Batsch]: isolation, characterisation and crossspecies amplification in Prunus. Theor Appl Genet 99:65-72

Crane MB, Lawrence WJC (1934) The genetics of garden plants. Macmillan, London

De Nettancourt D (2001) Incompatibility and incongruity in wild and cultivated plants. Springer-Verlag, New York

Decroocq V, Hagen LS, Favé MG, Eyquard JP, Pierronnet A (2004) Microsatellite markers in the hexaploid Prunus domestica species and parentage lineage of three European plum cultivars using nuclear and chloroplast simple-sequence repeats. Mol Breed 13:135-142

Dirlewanger E, Cosson P, Tavaud M, Aranzana M, Poizat C, Zanetto A, Arús P, Laigret F (2002) Development of microsatellite markers in peach [Prunus persica (L.) Batsch] and their use in genetic diversity analysis in peach and sweet cherry (Prunus avium L.). Theor Appl Genet 105:127-138

Eimert K, Hüwe U, Rückert FE (2016) Evaluation of genetic differentiation of autochthonous sloe (Prunus spinosa Rosaceae) populations across Germany using molecular markers. Plant Ecol Evol 149(3):280-290 
Erturk Y, Ercisli S, Maghradze D, Orhan E, Agar G (2009) An assessment of genetic variability and relationships among wild-grown blackthorn (Prunus spinosa L.) plants based on RAPD markers. Genet Mol Res 8:1238-1244

Erturk Y, Ercisli S, Tosun M (2012) Physico-chemical characteristics of wild plum fruits (Prunus spinosa L.). Int J Plant Prod 3:89-92

Eryomine GV (1990) New data on origin of Prunus domestica L. Acta Hortic 283:27-30

Faust M, Surányi D (1999) Origin and dissemination of plums. Hort Rev 23:179-231

Guitian J, Guitian P, Sanchez JM (1993) Reproductive biology of 2 Prunus species (Rosaceae) in the Northwest Iberian Peninsula. Plant Syst Evol 185:153-165

Guzmán FA, Segura S, Aradhya M, Potter D (2018) Evaluation of the genetic structure present in natural populations of four subspecies of black cherry (Prunus serotina Ehrh.) from North America using SSR markers. Sci Hortic Amsterdam 232:206-215

Halász J, Hegedús A, György Z, Pállinger É, Tóth M (2011) S-genotyping of old apple cultivars from the Carpathian basin: methodological, breeding and evolutionary aspects. Tree Genet Genomes $7: 1135-1145$

Halász J, Kodad O, Galiba GM, Skola I, Ercisli S, Ledbetter CA, Hegedús A (2019) Genetic variability is preserved among strongly differentiated and geographically diverse almond germplasm: an assessment by simple sequence repeat markers. Tree Genet Genomes 15:12. https://doi.org/10.1007/ s11295-019-1319-8

Hall TA (1999) BioEdit: a user-friendly biological sequence alignment editor and analysis program for Windows 95/98/NT. Nucl Acid Symp Ser 41:95-98

Halliday G, Beadle M (1983) Flora Europaea. Cambridge University Press, Cambridge

Hammer R, Harper DAT, Ryan PD (2001) PAST: paleontological statistics software package for education and data analysis. Palaeontol Electron 4:1-9

Hauck NR, Yamane H, Tao R, Iezzoni AF (2006) Accumulation of nonfunctional $S$-haplotypes results in the breakdown of gametophytic self-incompatibility in tetraploid Prunus. Genetics 172:1191-1198

Hegedús A, Lénárt J, Halász J (2012) Review of sexual incompatibility in tree fruit species: molecular interactions and evolutionary dynamics. Biol Plant 56:201-209

Hildebrand CE, Torney DC, Wagner RP (1992) Informativeness of polymorphic DNA markers. Los Alamos Sci 20:100-102

Horvath A, Balsemin E, Barbot JC, Christmann H, Manzano G, Reynet P, Laigret F, Mariette S (2011) Phenotypic variability and genetic structure in plum (Prunus domestica $L$.), cherry plum (P. cerasifera Ehrh.) and sloe (P. spinosa L.). Sci Hortic-Amsterdam 129:283-293

Howad W, Yamamoto T, Dirlewanger E, Testolin R, Cosson P, Cipriani G, Monforte AJ, Georgi L, Abott AG, Arus P (2005) Mapping with a few plants: using selective mapping for microsatellite saturation of the Prunus reference map. Genetics 171(3):1305-1309

Kato S, Iwata H, Tsumura Y, Mukai Y (2011) Genetic structure of island populations of Prunus lannesiana var. speciosa revealed by chloroplast DNA, AFLP and nuclear SSR loci analyses. J Plant Res 124:11-23

Kodad O, Sánchez A, Saibo N, Oliveira M, Sociasi Company R (2008) Identification and characterization of new $S$-alleles associated with self-incompatibility in almond. Plant Breed 127:632-638

Kodad O, Hegedús A, Halász J (2013) Self-(in) compatibility genotypes of Moroccan apricots indicate differences and similarities in the crop history of European and North African apricot germplasm. BMC Plant Biol 13:1

Kota-Dombrovska I, Lācis G (2013) Evaluation of self-incompatibility locus diversity of domestic plum (Prunus domestica L.) using DNA-based S-genotyping. Proc Latvian Acad Sci B 67:109-115

Kovács Sz (2015) Vadgyümölcsök a kertben és ültetvényekben. Cser Kiadó, Budapest

Lacape JM, Dessauw D, Rajab M, Noyer JL, Hau B (2007) Microsatellite diversity in tetraploid Gossypium germplasm: assembling a highly informative genotyping set of cotton SSRs. Mol Breed 19:45-58

Lācis G, Rashal I, Trajkovski V (2011) Implementation of a limited set of SSR markers for screening of genetic variability in Latvian and Swedish sour cherry (Prunus cerasus L.) genetic resources collections. Proc Latvian Acad Sci B 65:21-28

Lapointe FJ, Legendre P (1992) Statistical significance of the matrix correlation coefficient for comparing independent phylogenetic trees. Syst Biol 41:378-384

Leinemann L, Kleinschmit J, Fussi B, Hosius B, Kuchma O, Arenhövel W, Lemmen P, Kätzel R, Rogge M, Finkeldey R (2014) Genetic composition and differentiation of sloe (Prunus spinosa L.) 
populations in Germany with respect to the tracing of reproductive plant material. Plant Syst Evol 300:2115-2125

Makovics-Zsohár N, Hegedús A, Halász J (2016) S-allele constitution of hexaploid European plum cultivars. Acta Hort 1231:151-156

Makovics-Zsohár N, Tóth M, Surányi D, Kovács S, Hegedús A, Halász J (2017) Simple sequence repeat markers reveal Hungarian plum (Prunus domestica L.) germplasm as a valuable gene resource. HortScience 52:1655-1660

Mason AS (2015) Challenges of genotyping polyploid species. In: Batley J (ed) Plant genotyping. Humana Press, New York, pp 161-168

Matton DP, Maes O, Laublin G, Xike Q, Bertrand C, Morse D, Cappadocia M (1997) Hypervariable domains of self-incompatibility RNases mediate allele-specific pollen recognition. Plant Cell 9:1757-1766

Messina R, Lain O, Marrazzo MT, Cipriani G, Testolin R (2004) New set of microsatellite loci isolated in apricot. Mol Ecol Notes 4(3):432-434

Mnejja M, Garcia-Mas J, Audergon JM, Arús P (2010) Prunus microsatellite marker transferability across rosaceous crops. Tree Genet Genomes 6:689-700

Mnejja M, Garcia J, Howad W, Badenes ML, Arús P (2004) Simple-sequence repeat (SSR) markers of Japanese plum (Prunus salicina Lindl.) are highly polymorphic and transferable to peach and almond. Mol Ecol Notes 4:163-166

Mnejja M, Garcias J, Howad W, Arús P (2005) Development and transportability across Prunus species of 42 polymorphic almond microsatellites. Mol Ecol Notes 5:531-535

Mohanty A, Martin JP, Aguinagalde I (2000) Chloroplast DNA diversity within and among populations of the allotetraploid Prunus spinosa L. Theor Appl Gen 100:1304-1310

Moncada P, McCouch S (2004) Simple sequence repeat diversity in diploid and tetraploid Coffea species. Genome 47:501-509

Nielsen J, Olrik DC (2001) A morphometric analysis of Prunus spinosa, P. domestica ssp. insititia, and their putative hybrids in Denmark. Nord J Bot 21:349-363

Nunes MD, Santos RA, Ferreira SM, Vieira J, Vieira CP (2006) Variability patterns and positively selected sites at the gametophytic self-incompatibility pollen $S F B$ gene in a wild self-incompatible Prunus spinosa (Rosaceae) population. New Phytol 172:577-587

Ortega E, Bošković RI, Sargent DJ, Tobutt KR (2006) Analysis of S-RNase alleles of almond (Prunus dulcis): characterization of new sequences, resolution of synonyms and evidence of intragenic recombination. Mol Genet Genom 276:413-426

Pairon M, Jacquemart AL, Potter D (2008) Detection and characterization of genome-specific microsatellite markers in the allotetraploid Prunus serotina. J Am Soc Hortic Sci 133:390-395

Potter D, Eriksson T, Evans RC, Oh S, Smedmark JEE, Morgan DR, Kerr M, Robertson KR, Arsenault M, Dickinson TA, Campbell CS (2007) Phylogeny and classification of Rosaceae. Plant Syst Evol 266:5-43

Reales A, Sargent DJ, Tobutt KR, Rivera D (2010) Phylogenetics of Eurasian plums, Prunus L. section Prunus (Rosaceae), according to coding and non-coding chloroplast DNA sequences. Tree Genet Genomes 6:37-45

Reynders-Aloisi S, Grellet F (1994) Characterization of the ribosomal DNA units in two related Prunus species (P. cerasifera and P. spinosa). Plant Cell Rep 13:641-646

Ruiz-Rodríguez BM, de Ancos B, Sánchez-Moreno C, Fernández-Ruiz V, de Cortes S-M, Cámara M, Tardío J (2014) Wild blackthorn (Prunus spinosa L.) and hawthorn (Crataegus monogyna Jacq.) fruits as valuable sources of antioxidants. Fruits 69:61-73

Sipos B, Szabó T (2004) Fruit species with special value (in Hungarian). In: Kodáry E (ed) Fruit crops of the Carpathian Basin. Zászlónk Stúdió, Budapest

Sonneveld T, Robbins TP, Tobutt KR (2006) Improved discrimination of self-incompatibility S-RNase alleles in cherry and high throughput genotyping by automated sizing of first intron polymerase chain reaction products. Plant Breed 125:305-307

Sonneveld T, Tobutt KR, Robbins TP (2003) Allele-specific PCR detection of sweet cherry selfincompatibility $(S)$ alleles $S_{1}$ to $S_{16}$ using consensus and allele-specific primers. Theor Appl Genet 107:1059-1070

Sutherland BG, Robbins TP, Tobutt KR (2004) Primers amplifying a range of Prunus S-alleles. Plant Breed 123:582-584

Sutherland BG, Tobutt KR, Robbins TP (2008) Trans-specific S-RNase and SFB alleles in Prunus selfincompatibility haplotypes. Mol Genet Genom 279:95-106 
Tamura K, Peterson D, Peterson N, Stecher G, Nei M, Kumar S (2011) MEGA5: molecular evolutionary genetics analysis using maximum likelihood, evolutionary distance, and maximum parsimony methods. Mol Biol Evol 28:2731-2739

Tsukamoto T, Hauck NR, Tao R, Jiang N, Iezzoni AF (2010) Molecular and genetic analyses of four nonfunctional $S$ haplotype variants derived from a common ancestral $S$ haplotype identified in sour cherry (Prunus cerasus L.). Genetics 184:411-427

Urrestarazu J, Errea P, Miranda C, Santesteban LG, Pina A (2018) Genetic diversity of Spanish Prunus domestica L. germplasm reveals a complex genetic structure underlying. PLoS ONE 13:e0195591

Ushijima K, Sassa H, Tao R, Yamane H, Dandekar AM, Gradziel TM, Hirano H (1998) Cloning and characterization of cDNAs encoding S-RNases from almond (Prunus dulcis): primary structural features and sequence diversity of the S-RNases in Rosaceae. Mol Gen Genet MGG 260(2):261-268

Vander Mijnsbrugge K, Depypere L, Chaerle P, Goetghebeur P, Breyne P (2013) Genetic and morphological variability among autochthonous Prunus spinosa populations in Flanders (northern part of Belgium): implications for seed sourcing. Plant Ecol Evol 146:193-202

Vieira J, Morales-Hojas R, Santos RA, Vieira CP (2007) Different positively selected sites at the gametophytic self-incompatibility pistil S-RNase gene in the Solanaceae and Rosaceae (Prunus, Pyrus, and Malus). J Mol Evol 65:175-185

Vieira J, Santos RAM, Ferreira SM, Vieira CP (2008) Inferences on the number and frequency of $S$-pollen gene (SFB) specificities in the polyploid Prunus spinosa. Heredity 101:351-358

Walsh PS, Erlich HA, Higuchi R (1992) Preferential PCR amplification of alleles: mechanisms and solutions. Genome Res 1:241-250

Wiersma PA, Wu Z, Zhou L, Hampson C, Kappel F (2001) Identification of new self-incompatibility alleles in sweet cherry (Prunus avium L.) and clarification of incompatibility groups by PCR and sequencing analysis. Theor Appl Genet 102:700-708

Wünsch A (2009) Cross-transferable polymorphic SSR loci in Prunus species. Sci Hortic 120:348-352

Wünsch A, Hormaza JI (2002) Molecular characterisation of sweet cherry (Prunus avium L.) genotypes using peach [Prunus persica (L.) Batsch] SSR sequences. Heredity 89:56-63

Xie H, Sui Y, Chang FQ, Xu Y, Ma RC (2006) SSR allelic variation in almond (Prunus dulcis Mill.). Theor Appl Genet 112:366-372

Yamane H, Tao R (2009) Molecular basis of self-(in)compatibility and current status of $S$-genotyping in Rosaceous fruit trees. J Jpn Soc Hort Sci 78:137-157

Yilmaz KU, Ercisli S, Asma BM, Dogan Y, Kafkas S (2009) Genetic relatedness in Prunus genus revealed by inter-simple sequence repeat markers. HortScience 44:293-297

Zhang QP, Liu DC, Liu S, Liu N, Wei X, Zhang AM, Liu WS (2014) Genetic diversity and relationships of common apricot (Prunus armeniaca L.) in China based on simple sequence repeat (SSR) markers. Genet Resour Crop Evol 61:357-368

Zhebentyayeva T, Shankar V, Scorza R, Callahan A, Ravelonandro M, Castro S, DeJong T, Saski CA, Dardick C (2019) Genetic characterization of worldwide Prunus domestica (plum) germplasm using sequence-based genotyping. Hortic Res 6:1-13

Zimmer J (2011) Die Schlehe (Prunus spinosa). DLR Rheinpfalz-Kompetenzzentrum Gartenbau, Rheinbach

Zuckerkandl E, Pauling L (1965) Evolutionary divergence and convergence in proteins. In: Bryson V, Vogel HJ (eds) Evolving genes and proteins. Academic Press, New York, pp 97-166

Publisher's Note Springer Nature remains neutral with regard to jurisdictional claims in published maps and institutional affiliations. 


\section{Authors and Affiliations}

Júlia Halász ${ }^{1}$ (D) N Noémi Makovics-Zsohár ${ }^{1} \cdot$ Ferenc Szőke $^{2} \cdot$ Sezai Ercisli ${ }^{3}$. Attila Hegedüs ${ }^{1}$

$\triangle$ Júlia Halász

genetics.prunus@gmail.com

1 Department of Genetics and Plant Breeding, Szent István University, Ménesi út 44., 1118 Budapest, Hungary

2 Lövőpetri, Hungary

3 Department of Horticulture, Faculty of Agriculture, Ataturk University, Erzurum, Turkey 